\title{
Siverek Yöresinde Yetiştirilen Kızıl Banki ve Bastık Kabarcık Üzüm Çeşitlerinin Organik Asit ve Şeker İçeriklerinin Belirlenmesi Üzerine Bir Araştırma
}

\author{
Aslı POLAT ${ }^{1 *}$, Mehmet KARAASLAN², Sadettin GÜRSÖZ ${ }^{3}$ \\ ${ }^{1}$ GAP Tarımsal Araştırma Enstitüsü Müdürlüğü, Şanlıurfa \\ ${ }^{2}$ Harran Üniversitesi Ziraat Fakültesi Gıda Mühendisliği Bölümü, Şanlıurfa \\ ${ }^{3}$ Harran Üniversitesi Ziraat Fakültesi Bahçe Bitkileri Bölümü, Şanlıurfa \\ *Sorumlu Yazar: asli.polat@tarim.gov.tr
}

\section{Öz}

Şanlıurfa ili, Siverek ilçesinde 2013 ve 2014 yıllarında gerçekleştirilen bu çalışmada, Kızıl Banki ve Bastık Kabarcık üzüm çeşitleri olgunlaşma döneminde hasat edilerek, organik asit ve şeker içerikleri bakımından incelenmişlerdir. Olgunlaşma döneminde şırada SÇKM, pH, titrasyon asitliği ölçülmüş ve olgunluk kriterlerine uygun dönemde hasat edilerek analize tabi tutulmuşlardır. Organik asit ve şeker analizleri HPLC cihazı ile belirlenmiştir. Araştırmada incelenen şekerlerden, fruktoz, glukoz, galaktoz ve sakkaroz Kızıl Banki çeşidinde sırasıyla, 4.53, 4.85, 3.14, 1.94 g 100g-1 Bastık Kabarcık çeşidinde ise 4.95, 6.22, 3.38, 3.03 g 100g-1 olarak saptanmıştır. Çalışmada Kızıl Banki ve Bastık Kabarcık çeşitleri L-tartarik, L-malik, D-malik, sitrik, oksalik ve fumarik asit içerikleri de incelenmiştir. Elde edilen bulgulara göre çeşitlerin L-tartarik, Lmalik, D-malik, sitrik, oksalik ve fumarik asit içerikleri sırasıyla Kızıl Banki çeşidinde 385, 69.7, 22.3, 6.41, 18.7, 0.228 mg 100g-1 iken Bastık Kabarcık çeşidinde 346, 35.8, 20.9, 6.72, 7.79, 0.130 mg 100g-1 olarak saptanmıştır. Üzümlerde yüksek oranda bulunan şekerler fruktoz ve glukoz iken tartarik asitin üzümde baskın olduğu ve bunu malik asitin takip ettiği, fumarik asitin ise eser miktarda bulunduğu görülmüştür.

Anahtar kelimeler: HPLC, Üzüm, Şanlıurfa

\section{A study on Determining Organic Acid and Sugar Ingredients of Kızıl Banki and Bastık Kabarcık Grape Varieties Grown in Siverek Area}

\begin{abstract}
At this study, carried in 2013 and 2014, Kızıl Banki and Bastık Kabarcık grape varieties grown in Siverek, Şanlıurfa were harvested at maturity period and they were studied on organic acid and sugar ingredients. TSS, $\mathrm{pH}$, total titratable acidity were measured at wort at maturity period and they were harvested at suitable period according to maturity criteria to be analysed. Organic acid and sugar analyses were measured by HPLC. Fructose, glucose, galactose and saccharose, the sugar varieties that were analysed during the study, were determined as 4.53, 4.85, 3.14, $1.94 \mathrm{~g} 100 \mathrm{~g}-1$ at Kızıl Banki while they were 4.95,

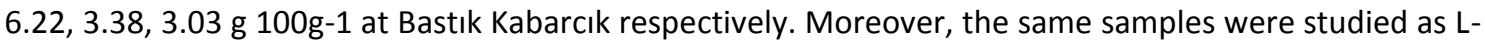
tartaric, L-malic, D-malic, citric, oxalic and fumaric acids and they were determined as 385, 69.7, 22.3, $6.41,18.7,0.228 \mathrm{mg} \mathrm{100g-1}$ at Kızıl Banki while they were 346, 35.8, 20.9, 6.72, 7.79, 0.130 mg $100 \mathrm{~g}-1$ at Bastık Kabarcık respectively. It was observed that while fructose and glucose were the sugar appearing at grapes highly, tartaric acid was dominant, followed by malic acid and fumaric acid was at trace quantity. Due to the difference at climate conditions, the data held was also different in years and it was observed that it was paralel for both varieties.
\end{abstract}

Key words: HPLC, Grape, Şanlıurfa 


\section{Giriş}

Siverek illçesinde bağcılık genel olarak antepfıstığı bahçesinde ara tarım olarak goble ve serpene terbiye sistemleriyle yapılmaktadır. Sulama imkanlarının kısıtı olması nedeniyle sulama yapılmamakta ve asmalar sadece külleme hastalığına karşı ilaçlanırken, antepfıstığı bahçesi hastalık ve zararılıara karşı ilaçlanmaktadır. Gelişen fıstık bahçesi içerisindeki asmalar zamanla kurumaya başlamaktadır. Bununla birlikte bağ alanlarının imara açılması, hastalık ve zararlılar, kuraklık gibi iklim koşullarının değişmesinden ve sulama imkanlarının kısıtlı olmasından dolayı yörede bağcılık gün geçtikçe gerilemektedir. Yörede şu anda mevcut olan Bastık Kabarcık (Şire), Kızıl Banki, Ağ Banki, Köseni, Hasani, Elma Üzümü çeşitlerinden sadece Bastık Kabarcık ve Kızıl Banki çeşitleri yaygın bir şekilde yetiştirilirken, diğer çeşitler yok olmaya yüz tutmuş durumdadır.

Üzüm meyvesi dünya üzerinde en çok gıda maddesine işlenen ve sofralık olarak da tüketilen meyvelerin başında gelmektedir. Çelik (2007), üzüm şırasının kimyasal bileşiminde $\% \quad 70-80$ su, $\%$ 15-25 karbonhidratlar (glikoz \% 8-13, fruktoz \% 712), \% 0.3-1.5 organik asitler (tartarik asit \% 0.2-1, malik asit \% 0.1-0.8, sitrik asit \% 0.010.05 ) bulunduğunu bildirmiştir. Buradan da anlaşıldığı üzere, üzümlerin bileşimindeki en önemli şekerler glikoz ve fruktozdur. Glikoz ve fruktoz şıradaki şekerlerin \% 99'unu, olgun tane ağırlığının ise \% 12-27'sini oluşturur (Winkler ve ark., 1974). Derim sırasında üzümlerdeki glikoz/fruktoz oranı çeşitlere göre farklılık göstermekle birlikte birçok üzüm çeşidinde bu oranın 0.79-1.14 arasında değiştiği belirtilmiştir (Artés-Hernández ve ark., 2004, 2006; Valero ve ark., 2006; Çelik, 2007). Yine Çelik (2007)'e göre sofralık üzüm çeşitlerinde SÇKM'nin \% 20.0-22.3 arasında olduğunda glikoz/fruktoz oranı $0.80-1.12$ arasında değişmektedir (Üstün, 2011).

Üzümlerdeki önemli organik asitler tartarik ve malik asit olup, toplam asitliğin \% 90'ından fazlasını oluştururlar (Cash ve ark., 1977; Kanellis ve Roubelakis-Angelakis, 1993; Patil ve ark., 1995). Sitrik asit de üzümlerde en fazla bulunan 3. organik asit olup, toplam asitliğin \% 5-10'unu oluşturmaktadır (Winkler ve ark., 1997). Üzümlerde bu asitlerin dışında okzalik, fumarik gibi organik asitler de vardır. Ancak, bunların varlığı tartarik, malik ve bir ölçüde de sitrik asit kadar önemli değildir (Çelik, 1998). Ayrıca; asetik, cis-aconitik, askorbik, cinnamik, isositrik, formik, galakturonik, gallik, glutarik, gliserik, glikolik, glyoxlik, o-hidroksibenzoik, phidroksibenzoik, $\alpha$-ketoglutarik, laktik, mandelic, mucic, okzaloasetik, fosforik, pyrolidone, karboksilik, pruvik, salisilik, shicimic ve süksinik asitler üzümlerde minimum düzeylerde bulunan diğer organik asitlerdir (Fuleki ve ark., 1993; Buhurcu, 2004).

Tüketim kriterlerinin ve değerlendirilme şekillerinin başında organik asit ve şeker içerikleri gelmektedir. Örneğin, üzümlerden elde edilen şarabın kalitesi için şıranın bazı aromatik maddelerce zengin ve organik asit içeriğinin de yüksek olması arzu edilir (Çelik ve ark., 1998).

$\mathrm{Bu}$ araştırma ile Siverek ilçesi için önem taşıyan Kızıl Banki ve Bastık Kabarcık üzüm çeşitlerinin daha doğru bir değerlendirme ve tüketim şekli ile çeşit özelliklerinin belirlenebilmesi amacıyla, organik asit ve şeker profilleri incelenmiştir.

\section{Materyal ve Metot}




\section{Materyal}

Materyal olarak Siverek yöresinde yetiştirilen Kızıl Banki ve Bastık Kabarcık üzüm çeşitleri kullanılmıştır.

Kızıl Banki üzüm çeşidi, orta mevsimde olgunlaşan sofralık bir üzüm çeşididir. Erdişi çiçek yapısına sahip olan çeşidin taneleri kırmızımsı renkte, kısa oval şekilli ve 2-3 çekirdeklidir. Salkımları omuzlu dallı şekilli ve sıktır (Gürsöz, 1993). Bu çeşitten örnek alınan omcalar, serpene terbiye sisteminde ve kapama bağ şeklinde yetiştirilmektedir. Bağda hastalık ve zararlılara karşı ilaçlama yapılmakta ancak sulama yapılmamaktadır. Çeşidin yetiştirildiği bağın toprak yapısı; killi olup, pH; 7.59, EC; 0.81 ds m-1, toplam kireç içeriği ise \% 2.25'tir.

Bastık Kabarcık çeşidi geççi bir sofralık üzüm çeşididir. Erdişi çiçek yapısına sahip olan çeşidin taneleri yeşil-sarı renkte, yuvarlak şekilli ve 2-3 çekirdeklidir. Salkımları konik omuzlu şekillidir (Gürsöz, 1993). Örnek alınan omcalar, goble terbiye sistemi ile fistık bahçesi içerisinde sıra aralarında yetiştirilmektedir. Bağda mildiyö ve küllemeye karşı ilaçlama yapılmış olup fıstık bahçesi hastalık ve zararlılara karşı ilaçlanmaktadır. Örnek alınan omcalar antepfıstığı ile karışık yetiştirildiğinden, sulama yapılmamaktadır. Bağın toprak yapısı; killi olup, pH; 7.59, EC; 0.91 ds m-1, toplam kireç içeriği ise \% 1.5'tir.

Kızıl Banki çeşidi 05.09.2013 ve 03.09.2014 tarihlerinde, Bastık Kabarcık çeşidi ise 12.09.2013 ve 11.09.2014 tarihlerinde hasat edilerek uygun koşullarda laboratuvara getirilmiştir. Üzümler önce saf su ile yıkanarak kurutulmuş ardından ekstraksiyon işlemine tabi tutulmuştur. Organik asit ve şeker analizlerinde kullanılan standartlardan malik asit Sigma Aldrich, diğer standartlar ise Merck firmasından temin edilmiştir.

\section{Ekstraksiyon}

Şekerler (glikoz, fruktoz, galaktoz, sakaroz) ve organik asitler (tartarik, malik, sitrik, fumarik ve okzalik asit) Pretel ve ark. (2006) tarafından bildirilen yöntem modifiye edilerek uygulanmıştır. Tesadüfi olarak seçilen 50 adet üzüm tanesi blender ile homojenize edilip, SIVI azot ile porselen havanda ezilerek $1 \mathrm{~g}$ doku örneği alınmış, üzerine $25 \mathrm{~mL}$ deiyonize su eklenmiştir. Bir dakika vorteks ile karıştırılmış ve daha sonra ultrasonik su banyosunda $50 \mathrm{oC}^{\prime}$ de 60 dakika bekletilmiştir. 9000 rpm hızda 30 dakika oda sıcaklığında santrüfüj edilmiş olup santrifüj sonunda süpernatantlar $0.45 \mu \mathrm{m}$ şırınga filtresi kullanılarak filtre edildikten sonra viallere aktarımıştır. Elde edilen ekstraktlar, HPLC cihazında şeker ve organik asitlerin analizinde kullanılmıştır. Şeker ve organik asit analizleri 3 tekerrürlü olarak yapılmıştır.

\section{Sekerlerin HPLC ile analizi}

Bireysel şekerlerin analizi HPLC cihazı ile izokritik yöntem ile yapılmıştır. Analizler Candir Ertürk ve ark. (2009)'nın metoduna göre yapılmıştır. Kromatogramlarda elde edilen şeker pikleri, şeker standartlarının alıkonma süresi karşılaştırılmasıyla tanımlanmıştır. Örnekteki bireysel şeker içerikleri uygun standartlar kullanılarak belirlenmiştir. Her bir standart için dört farklı konsantrasyonda çözelti hazırlanıp HPLC'ye enjekte edilerek kalibrasyon eğrileri oluşturulmuş ve elde edilen eğrilerden bireysel şeker içerikleri hesaplanarak, ppm olarak ifade edilmiştir. HPLC cihazı: HP 1100 Series, Dedektör: RID HP 1047A Series, Pump: HP 1100 eries G1311A Quatpump, System controller: HP 1100 Series G1313A ALS, Degasser: HP 1100 Series G1322A, Column oven: HP 1100 Series G1316A Colcomp, Kolon: Agilent Carbohydrate $(250 \times 4.6 \mathrm{~mm}) 5$ 
$\mu \mathrm{m}$, Enjeksiyon hacmi: $10 \mu \mathrm{m}$, akış hızı: $2 \mathrm{ml}$ dk-1, Kolon fırını sıcaklığı: $300 \mathrm{C}$, Mobil faz: Deiyonize su/Asetonitril (20/80:v/v).

\section{Organik asitlerin HPLC ile analizi}

Organik asitlerin analizi de HPLC cihazı ile izokritik metotla yapılmıştır. Pretel ve ark. (2006) tarafından önerilen yöntem modifiye edilerek uygulanmıştır. Kromatogramlarda elde edilen organik asit pikleri, organik asit standartlarının alıkonma sürelerinin karşılaştırımasıyla tanımlanmıştır. Örnekteki organik asit içerikleri; "malik, sitrik, tartarik, fumarik ve okzalik asit" uygun standartlar kullanılarak belirlenmiştir. Her bir standart için farklı konsantrasyonlarda çözelti hazırlanıp HPLC'ye enjekte edilerek kalibrasyon eğrileri oluşturulmuş ve elde edilen eğrilerden organik asit içerikleri hesaplanarak, ppm olarak belirtilmiştir. HPLC cihazı: HP 1100 Series, Dedektör: DAD HP 1100 Series, Pump: HP 1100 eries G1311A Quatpump, System controller: HP 1100 Series G1313A ALS, Degasser: HP 1100 Series G1322A, Column oven: HP 1100 Series G1316A Colcomp, Kolon: Agilent Eclipse XDBC18 (250x4.6 mm) $5 \mu \mathrm{m}$, Enjeksiyon hacmi: 20 $\mu \mathrm{m}$, Akış hızı: $0.5 \mathrm{ml} / \mathrm{dk}$, Kolon fırını sıcaklığı: $40^{\circ} \mathrm{C}$, Mobil faz: $25 \mathrm{mM} \mathrm{KH} \mathrm{PO}_{4}(\mathrm{pH}: 2.4)$, Dalga boyu: $210 \mathrm{~nm}$.

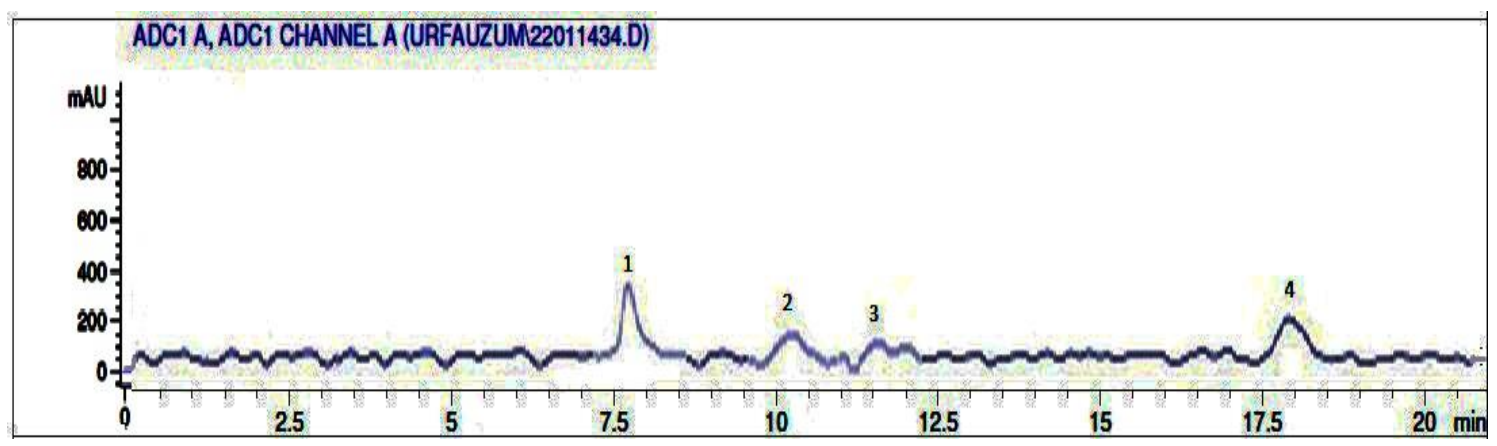

Şekil 1. Araştırmada kullanılan şeker standartlarına ait kromatogram

Figure 1. The chromatogram of a standard mixture of sugars

*Şeker standartlarına ait pikler 1)Fruktoz, 2)Glukoz, 3)Galaktoz, 4)Sakkaroz

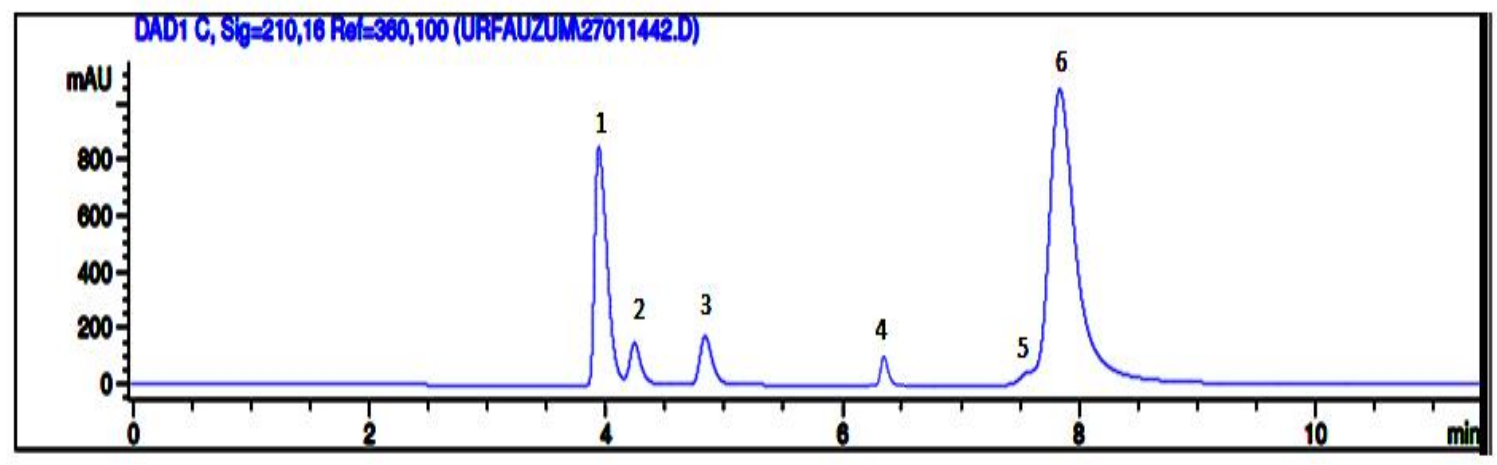

Şekil 2. Araştırmada kullanılan organik asit standartlarına ait kromatogram

Figure 2. The chromatogram of a standard mixture of organic acids

*Organik asit standartlarına ait pikler 1) Oksalik asit, 2) L-tartarik asit, 3) L-Malik asit, 4) Sitrik asit, 5)Fumarik asit, 6) D-Malik asit 
Istatistik Analizler

Araştırmada elde edilen veriler tesadüf blokları deneme desenine göre JUMP istatistik paket programından yararlanılarak varyans analizine tabi tutulmuş ve değerlendirilmiştir. Değerler arasındaki önemlilik derecesi Least Significant Difference Test'ine (LSD) göre gruplandırılmıştır.

\section{Araştırma Bulguları ve Tartışma}

Şanlıurfa İli, Siverek ilçesinde 2013 ve 2014 yıllarında yürütülen bu çalışmada, olgunlaşma döneminde hasat edilen üzümlerde öncelikle olgunluk kriterleri olan SÇKM, pH, titrasyon asitliği ve olgunluk indisi değerleri ölçülmüştür. Üzüm çeşitlerinin SÇKM, pH, titre edilebilir asit ve olgunluk indisi değerleri birbirinden farklı olup çeşitler arasındaki farklılıklar her iki gözlem yılı için de istatistiksel olarak önemli bulunmuştur (Çizelge 1). Üzüm çeşitlerinde hasat zamanı, çeşitlere ve üretim bölgelerine göre değişmektedir. Hasat zamanının belirlenmesinde temel kriterlerden biri olan SÇKM değeri, Türk Standartları Enstitüsü Sofralık Üzüm Standardına göre çekirdekli çeşitlerde en az $\% 13$, çekirdeksiz çeşitlerde ise en az \% 14 olması istenir. Hasat edilen çeşitlerin SÇKM değerleri, Bastık Kabarcık çeşidinde \% 18.7 iken, Kızıl Banki çeşidinde bu değer \% 16.5 olarak belirlenmiştir. Bir diğer önem arz eden olgunluk kriteri olan olgunluk indisinin, erkenci çeşitlerde $20 / 1$, orta mevsim çeşitlerinde $25 / 1$ ve geççi çeşitlerde ise 30-35/1 olması istenir (Winkler ve ark., 1974; Karaçalı, 2004). Hasat edilen çeşitlerin olgunluk indisi değerleri, Bastık Kabarcık çeşidinde \% 42.1 iken, Kızıl Banki çeşidinde bu değer \% 52.5 olarak belirlenmiştir.

Siverek yöresinde yetiştiriciliği yapılan üzüm çeşitlerinde analiz sonucu saptanan şeker miktarları Çizelge 2 . de verilmiştir. Olgunlaşmaya başlayan üzümlerde şeker miktarı giderek artmaktadır. Olgun üzümlerde ise fruktoz ve glukoz değerleri (Bastık Kabarcık 4.95, 6.22 g 100g-1; Kızıl Banki 4.53, $4.85 \mathrm{~g} 100 \mathrm{~g}-1$ ) birbirine yakındır. Her iki üzüm çeşidinde de fruktoz baskın şeker görülürken, glukoz ikinci sırada yer almış bunu da galaktoz ve sakkaroz takip etmiştir. Şekerler üzümlerde olgunluk kriteridir ve glukozun fruktoza olan oranı, olgunluk süreci içersinde önemli ölçüde değişmektedir. Olgunlaşmanın başlangıcında glukoz oranı fazlayken, olgun dönemde glukoz ve fruktoz miktarı genellikle birbirine eşit olmaktadır. Ancak, aşırı olgun tanelerde ise fruktoz miktarı daha fazla olmaktadır (Yavaş ve Fidan, 1986, Anonim, 2010). Hasat döneminde üzümlerdeki glikoz/fruktoz oranı çeşitlere göre farklılık göstermekle birlikte birçok üzüm çeşidinde bu oran 0.79-1.14 arasında değişmektedir (Artés-Hernández ve ark., 2004; 2006; Valero ve ark., 2006; Çelik, 2007).

Liu ve ark. (2006), iki yıl süreyle 98 adet üzüm çeşidinde yapmış oldukları çalışma sonucuna, glikoz ve fruktozun üzümlerde hakim şekerler olduğunu, glikozun 45.9-122 mg mL-1 bulunduğunu saptamışlardır (Üstün, 2011). Yağcı (2004), 2001 ve 2002 yıllarında 25 çekirdeksiz üzüm tiplerinde yaptıkları araştırmada, galaktozun \% 1.03 - 1.76 arasında olduğunu bildirmiştir. Sakaroz üzümün bitki içerisinde taşınan formu olup, glikozdan sentezlenip bitki içerisinde depolanırken farklı formlara dönüşmektedir. Üzümlerde de depolanan şeker formu glikoz ve fruktoz olduğu için üzüm içerisinde sakkaroz miktarı bazı üzüm çeşitleri haricinde oldukça az bulunmaktadır. Gürcan ve Pala (1996), 21 değişik taze meyvede bulunan basit şekerlerin miktarını yüksek basınçı sıvı kromatografi tekniği ile belirlemişlerdir. Bu çalışmada Müşküle üzüm çeşidinde \% 0.22 sakkaroz bulunurken; Sultani üzüm çeşidinde ise sakkaroz ise hiç bulunamamıştır. 
Bastık Kabarcık ve Kızıl Banki üzüm çeşitleri hasattan sonra tartarik, malik, sitrik, fumarik ve oksalik asit içerikleri incelenmiştir. Organik asit değerlerine ait veriler istatiksel analizlerle Çizelge. $3^{\prime}$ te verilmiştir. Her iki çeşitte de en yüksek organik asit miktarı tartarik asit olduğu görülürken, bunu sırasıyla malik asit ve sitrik asit takip etmektedir. Düşük miktarlar da olsa oksalik ve fumarik aside de rastlanılmıştır. Yıllara göre değerlendirildiğinde yine en yüksek oran tartarik aside ait iken 2014 yılında tartarik asit değerlerinde düşüş, malik asit değerlerinde ise artış görülmüştür. Organik asitlerin miktarı mevsim sıcaklıklarına bağlı olarak önemli ölçüde değişmektedir. iklimin serin geçtiği dönemlerde şırada genel asitlik oranının yüksek olduğu bildirilmiştir (Çelik, 1998). Üzümlerdeki önemli iki organik asit olan tartarik ve malik asit toplam asitliğin \% 70-90'ını oluşturmaktadır (Yavaş ve Fidan, 1986). Buhurcu (2004), organik asit miktarlarının tane gelişim dönemlerine göre önemli ölçüde değiştiği; tartarik asidin üzüm tanelerin olgunlaşma süresince azaldığı ve olgunlukta en düşük seviyelere indiğini bildirmiştir. Yağcı (2004), 2001 ve 2002 yıllarında 25 çekirdeksiz üzüm tiplerinde tartarik asitin \% 0.52 - 1.02 arasında olduğunu ve tartarik asit/malik asit oranının 4.0-12.7 arasında değiştiğini bildirmiştir.

\section{Sonuçlar}

Sonuç olarak, olgunluk döneminde hasat edilen üzümlerde fruktoz, glikoz, galaktoz ve sakkaroz şekerlerinin yüksek oranda bulunduğu, baskın şekerin fruktoz ve glikoz olduğu saptanmıştır. Çeşitlerde yıllar arasında şeker bakımından istatistiksel açıdan farklar önemli bulunmuştur. Organik asitlerde ise tartarik asidin her iki çeşitte de baskın olduğu bunu malik asidin takip ettiği görülmüştür. Üzümlerde bulunan organik asitler çeşitlere göre ve yıllara göre değişim gösterirken bu değişkenlik istatistik analiz açısından da önemli bulunmuştur.

Analiz sonuçlarından elde edilen veriler değerlendirildiği zaman, Bastık Kabarcık üzüm çeşidinin şeker içeriği Kızıl Banki üzüm çeşidine göre daha yüksek olduğu, asit içeriğinin ise daha düşük olduğu görülmüştür. Bu üzüm çeşitlerinin tane yapıları (Bastık Kabarcık; sulu, ince kabuklu; Kızıl Banki; iri, sert, etli, kalın kabuklu) da göz önünde bulundurulduğu zaman Bastık Kabarcık üzüm çeşidinin şıralık, Kızıl Banki üzüm çeşidinin ise sofralık olarak değerlendirilmesi uygun görülmüştür.

\section{Ekler}

$\begin{array}{lll}\mathrm{Bu} & \text { çalışma } & \text { TAGEM }\end{array}$ (TAGEM/BBAD/14/A08/P04/08 no' lu proje) tarafından desteklenmiştir. Bu çalışmada kullanılan veriler Aslı POLAT 'ın doktora tez çalışmasından alınmıştır.

\section{Kaynaklar}

Anonim, 2010. FAO Database. http://faostat.fao.org/site/567/DesktopDe fault.aspx?PagelD=567\#ancor (Erişim tarihi:21.01.2012)

Artes-Hernandez, F., Aguayo, E., Artes, F., 2004. Alternative Atmosphere Treatments for Keeping Quality of 'Autumn Seedless' Table Grapes During Long-Term Cold Storage. Postharvest Biology and Technology, 31(1): 59-67.

Artes-Hernandez, Tomas-Barberan, F.A., Artes F., 2006. Modified Atmosphere Packaging Preserves Quality of SO2-free 'Superior Seedless' Table Grapes. Postharvest Biology and Technology, 39(2): 146-154.

Buhurucu, H., 2004. Bazı Şaraplık Üzüm Çeşitlerinde Farklı Gelişme Dönemlerinde Tanelerdeki Organik Asit Dağılımı. SDÜ, Fen Bilimleri Enst. Yüksek Lisans Tezi, Isparta, $33 \mathrm{~s}$

Candır Erturk, E., Ozdemir, A.E., Kaplankıran, M., Toplu, C., 2009. Physico-Chemical Changes During Growth of Persimmon Fruits in the 
East Mediterranean Climate Region. Scientia Horticulturae, 121: 42-48.

Cash, J.N., Sistrunk, W.A., Stutle, C.A., 1977. Changes in Non Volatile Acids of Concord Grapes During Maturation. Journal of Food Science, 42: 543-544.

Çelik, S., 1998. Bağcılık. Cilt-1. Anadolu Matbaa Amb. San. ve Tic. Ltd. Şti., Tekirdağ, $426 \mathrm{~s}$.

Çelik, S., 2007. Bağcılık (Ampeloloji). Anadolu Matbaa Amb. San. ve Tic. Ltd. Şti. Cilt 1, Tekirdağ, $482 \mathrm{~s}$.

Çelik, H., Ağaoğlu, Y.S., Fidan, Y., Marasalı, B., Söylemezoğlu, G., 1998. Sun Fidan A.S Mesleki Kitaplar Serisi:1. Genel Bağcılık. Ankara.

Fuleki, T., Pelayo, E., Palabay, R., 1993. Carboxylic Acid Composition of Authentic Varietal and Commercial Grape Juices, Journal of AOAC International, 76: 591-600.

Gürsöz, S., 1993. GAP Alanına Giren Güneydoğu Anadolu Bölgesi Bağcılığı ve Özellikle Şanlıurfa İlinde Yetiştirilen Üzüm Çeşitlerinin Ampelografik Nitelikleri ile Verim ve Kalite Unsurlarının Belirlenmesi Üzerinde Bir Araştırma. Doktora Tezi, Çukurova Üniversitesi, Fen Bilimleri Enstitüsü, Bahçe Bitkileri Anabilim Dalı, Adana, $363 \mathrm{~s}$.

Kanellis, A.K., Roubelakis-Angelakis, K.A., 1993. Grape. In G. B. Seymour, J.E. Taylor, \& G.A. Tucker (Eds.), Biochemistry of Fruit Ripen (pp. 189-220). London: Chapman \& Hall.

Karaçalı, İ., 2004. Bahçe Ürünlerinin Muhafazası ve Pazarlaması. Ege Üniversitesi Basımevi, pp: 472, İzmir.

Liu, H.F., Wu, B.H., Fan, P.G., Li, S.H., Li, L.S., 2006. Sugar and Acid Concentrations in 98 Grape Cultivars Analyzed by Principal Component Analysis. Journal of the Science of Food and Agriculture. 86:1526-1536.

Patil, V.K., Chakrawar, V.R., Narwadkar, P.R., Shinde, G.S., 1995. Grape: In D.K. Salunke and S.S. Kadam (Eds), Handbook of Fruit Science and Technology (pp.7-38).New York:Marcel Dekker.

Pretel, M.T., Martinez-Madrid, M.C., Martınez, J.R., Carreno, J.C.E., Romojaro, F., 2006. Prolonged Storage of 'Aledo' Table Grapes in a Slightly $\mathrm{CO} 2$ Enriched Atmosphere in Combination with Generators of SO2. LWT - Food Science and Technology, 39(10): 1109-1116.

Üstün, D., 2011. Modifiye Atmosferde Paketleme Ve Etanol Buharı Uygulamalarının Soğukta Muhafaza Sırasında Red Globe Üzüm
Çeşidinin Kimyasal Bileşimine ve Antioksidan Kapasitesine Etkileri. Mustafa Kemal Ünv., Fen Bilimleri Enst., Yüksek Lisans Tezi, Hatay, $97 \mathrm{s.}$

Valero, D., Valverde, J.M., Martinez-Romero, D., Guillen, F., Castillo, S., Serrano, M., 2006. The Combination of Modified Atmosphere Packaging With Eugenol or Thymol to Maintain Quality, Safety and Functional Properties of Table Grapes. Postharvest Biology and Technology, 41:317-327.

Yavaş. i., Fidan, Y., 1986. Üzümün İnsan Beslenmesindeki Değeri. Gıda Sanayinin Sorunları ve Serbest Bölgenin Gıda Sanayine Beklenen Etkisi Sempozyumu. 1517 Ekim, Adana, s: 225-236.

Yağcı, A., 2004. Yuvarlak ve Sultani Çekirdeksiz Üzüm Çeşitlerine Ait Bazı Tiplerin Şeker, Organik Asit, Protein ve Mineral Madde İçeriklerinin Belirlenmesi Üzerinde Araştırmalar. Ege Ünv. Fen Bilimleri Enst. Bahçe Bitkileri ABD, Doktora Tezi, İzmir, $160 \mathrm{~s}$.

Winkler, A.J., Cook, J.A., Kliewer, W.M., Lider, L.A., 1974. General Viticulture. University of California Press. Berkeley. California. 710 p.

Winkler, A.J., Cook, J.A., Kliewer, W.M., Lider, L.A., 1997. General Viticulture. Univ. Calif. Press, Berkeley and Los Angeles, 710 p. 
Çizelge 1. Üzümlerin olgunluk kriterlerine ait değerler

Table 1. Criteria values the maturity of the grapes

\begin{tabular}{|c|c|c|c|c|c|c|c|c|c|c|c|c|}
\hline \multirow{2}{*}{$\begin{array}{l}\text { Çeşit } \\
\text { Variety }\end{array}$} & \multicolumn{3}{|c|}{$\begin{array}{l}\text { SÇKM (\%) } \\
\text { TSS (\%) }\end{array}$} & \multicolumn{3}{|c|}{$\begin{array}{l}\mathrm{pH} \\
\mathrm{pH}\end{array}$} & \multicolumn{3}{|c|}{$\begin{array}{l}\text { Titrasyon asitliği (\%) } \\
\text { Titratable acidity (\%) }\end{array}$} & \multicolumn{3}{|c|}{$\begin{array}{l}\text { Olgunluk indisi (\%) } \\
\text { Maturity index (\%) }\end{array}$} \\
\hline & 2013 & 2014 & $\begin{array}{l}\text { Yillar ort. } \\
\text { Average } \\
\text { of years }\end{array}$ & 2013 & 2014 & $\begin{array}{c}\text { Yıllar ort. } \\
\text { Average } \\
\text { of years }\end{array}$ & 2013 & 2014 & $\begin{array}{c}\text { Yıllar ort. } \\
\text { Average } \\
\text { of years }\end{array}$ & 2013 & 2014 & $\begin{array}{c}\text { Yillar ort. } \\
\text { Average } \\
\text { of years }\end{array}$ \\
\hline Bastık Kabarcık & $19.2 \mathrm{a}$ & $18.2 \mathrm{a}$ & $18.7 \mathrm{a}$ & $3.39 \mathrm{~b}$ & $3.65 b$ & $3.52 b$ & $0.416 a$ & $0.478 a$ & $0.447 \mathrm{a}$ & $46.3 \mathrm{~b}$ & $38.0 \mathrm{~b}$ & $42.1 \mathrm{~b}$ \\
\hline Kızıl Banki & $16.2 \mathrm{~b}$ & $16.7 \mathrm{~b}$ & $16.5 \mathrm{~b}$ & $3.88 \mathrm{a}$ & $4.28 \mathrm{a}$ & $4.08 a$ & $0.277 b$ & $0.361 \mathrm{~b}$ & $0.319 \mathrm{~b}$ & $58.6 \mathrm{a}$ & $46.3 \mathrm{a}$ & $52.5 \mathrm{a}$ \\
\hline$C V(\%)$ & 0.29 & 1.63 & 1.16 & 0.87 & 0.54 & 0.71 & 3.31 & 1.23 & 2.32 & 4.10 & 1.67 & 3.38 \\
\hline Çeşit LSDo.05 & $0.19^{*}$ & $1.00^{*}$ & $0.32^{*}$ & $0.11^{*}$ & $0.07^{*}$ & $0.04^{*}$ & $0.04^{*}$ & $0.01^{*}$ & $0.01^{*}$ & $7.56^{*}$ & $2.48^{*}$ & $2.56^{*}$ \\
\hline Çeşit*YII LSD0.05 & & & $0.46^{*}$ & & & $0.06^{*}$ & & & Ö. D. & & & Ö. D. \\
\hline
\end{tabular}

*: \% 5 önem seviyesinde önemli, Ö.D. Önemli değil

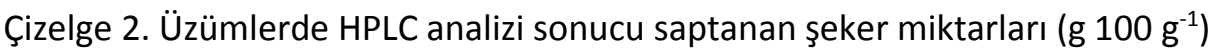

Table 2. Values of sugars determined by HPLC in grape samples $\left(g 100 \mathrm{~g}^{-1}\right)$

\begin{tabular}{|c|c|c|c|c|c|c|c|c|c|c|c|c|}
\hline \multirow[b]{2}{*}{$\begin{array}{l}\text { Çeşit } \\
\text { Variety }\end{array}$} & \multicolumn{3}{|c|}{$\begin{array}{l}\text { Fruktoz } \\
\text { Fructose }\end{array}$} & \multicolumn{3}{|c|}{$\begin{array}{l}\text { Glukoz } \\
\text { Glucose }\end{array}$} & \multicolumn{3}{|c|}{$\begin{array}{l}\text { Galaktoz } \\
\text { Galactose }\end{array}$} & \multicolumn{3}{|c|}{$\begin{array}{c}\text { Sakkaroz } \\
\text { Saccharose }\end{array}$} \\
\hline & 2013 & 2014 & $\begin{array}{c}\text { Yillar ort. } \\
\text { Average of } \\
\text { years }\end{array}$ & 2013 & 2014 & $\begin{array}{c}\text { Yillar ort. } \\
\text { Average } \\
\text { of years }\end{array}$ & 2013 & 2014 & $\begin{array}{c}\text { Yillar ort. } \\
\text { Average of } \\
\text { years }\end{array}$ & 2013 & 2014 & $\begin{array}{c}\text { Yillar ort. } \\
\text { Average } \\
\text { of years }\end{array}$ \\
\hline Bastık Kabarcık & $4.91 \mathrm{a}$ & $4.99 \mathrm{a}$ & $4.95 \mathrm{a}$ & $6.03 a$ & $6.41 \mathrm{a}$ & $6.22 \mathrm{a}$ & $2.71 \mathrm{a}$ & $4.05 \mathrm{a}$ & $3.38 \mathrm{a}$ & $3.11 \mathrm{a}$ & $3.04 \mathrm{a}$ & $3.08 \mathrm{a}$ \\
\hline Kızıl Banki & $4.64 \mathrm{~b}$ & $4.41 \mathrm{~b}$ & $4.53 \mathrm{~b}$ & $3.26 b$ & $6.43 a$ & $4.85 b$ & $2.73 a$ & $3.55 b$ & $3.14 b$ & $1.76 \mathrm{~b}$ & $2.12 b$ & $1.94 \mathrm{~b}$ \\
\hline CV (\%) & 0.83 & 0.89 & 0.86 & 2.97 & 1.07 & 1.97 & 1.63 & 1.14 & 1.34 & 4.44 & 4.22 & 4.33 \\
\hline Çeşit $L S D_{0.05}$ & $0.14^{*}$ & $0.14^{*}$ & $0.06^{*}$ & $0.48^{*}$ & Ö.D. & $0.17^{*}$ & Ö.D. & $0.15^{*}$ & $0.07^{*}$ & $0.38^{*}$ & $0.38^{*}$ & $0.17^{*}$ \\
\hline Çeşit* YII LSD 0.05 & & & $0.09^{*}$ & & & $0.24^{*}$ & & & $0.09^{*}$ & & & $0.24^{*}$ \\
\hline
\end{tabular}

*: \% 5 önem seviyesinde önemli, Ö.D. Önemli değil 
Çizelge 3. Üzümlerde HPLC analizi sonucu saptanan organik asit miktarları (mg $\left.100 \mathrm{~g}^{-1}\right)$

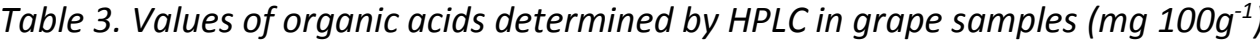

\begin{tabular}{|c|c|c|c|c|c|c|c|c|c|c|c|c|c|c|c|c|c|c|}
\hline \multirow[b]{2}{*}{$\begin{array}{l}\text { Çeşit } \\
\text { Variety }\end{array}$} & \multicolumn{3}{|c|}{$\begin{array}{l}\text { L-tartarik } \\
\text { L-tartaric }\end{array}$} & \multicolumn{3}{|c|}{$\begin{array}{l}\text { L-malik } \\
\text { L-malic }\end{array}$} & \multicolumn{3}{|c|}{$\begin{array}{l}\text { D-malik } \\
D \text {-malic }\end{array}$} & \multicolumn{3}{|c|}{$\begin{array}{l}\text { Sitrik } \\
\text { Citric }\end{array}$} & \multicolumn{3}{|c|}{$\begin{array}{c}\text { Oksalik } \\
\text { Oxalic }\end{array}$} & \multicolumn{3}{|c|}{$\begin{array}{l}\text { Fumarik } \\
\text { Fumaric }\end{array}$} \\
\hline & 2013 & 2014 & $\begin{array}{l}\text { Yillar } \\
\text { ort. } \\
\text { Avg of } \\
\text { years }\end{array}$ & 2013 & 2014 & $\begin{array}{c}\text { Yillar } \\
\text { ort. } \\
\text { Avg of } \\
\text { years }\end{array}$ & 2013 & 2014 & \begin{tabular}{|} 
Yillar \\
ort. \\
Avg of \\
years
\end{tabular} & 2013 & 2014 & \begin{tabular}{|} 
Yillar \\
ort. \\
Avg of \\
years
\end{tabular} & 2013 & 2014 & $\begin{array}{l}\text { Yillar } \\
\text { ort. } \\
\text { Avg of } \\
\text { years }\end{array}$ & 2013 & 2014 & $\begin{array}{c}\text { Yillar } \\
\text { ort. } \\
\text { Avg of } \\
\text { years }\end{array}$ \\
\hline Bastık Kabarcık & $369 \mathrm{~b}$ & 324 a & $346 \mathrm{~b}$ & $15.2 \mathrm{~b}$ & $56.4 \mathrm{~b}$ & $35.8 \mathrm{~b}$ & $11.9 \mathrm{~b}$ & $29.8 a$ & $20.9 \mathrm{~b}$ & $7.15 \mathrm{a}$ & $6.28 \mathrm{a}$ & $6.72 \mathrm{a}$ & $10.9 \mathrm{~b}$ & $4.68 \mathrm{~b}$ & $7.79 \mathrm{~b}$ & $0.09 \mathrm{~b}$ & $0.17 \mathrm{~b}$ & $0.13 \mathrm{~b}$ \\
\hline Kızıl Banki & $395 \mathrm{a}$ & $375 a$ & 385 a & $66.0 \mathrm{a}$ & $73.4 \mathrm{a}$ & 69.7 a & $19.0 \mathrm{a}$ & $25.6 \mathrm{~b}$ & $22.3 \mathrm{a}$ & $7.24 \mathrm{a}$ & $5.57 \mathrm{~b}$ & $6.41 \mathrm{~b}$ & $22.4 \mathrm{a}$ & $14.9 \mathrm{a}$ & $18.7 \mathrm{a}$ & $0.25 \mathrm{a}$ & $0.21 \mathrm{a}$ & $0.23 a$ \\
\hline CV (\%) & 0.00 & 4.66 & 3.28 & 2.24 & 4.47 & 4.08 & 4.33 & 2.73 & 3.31 & 1.71 & 2.63 & 2.14 & 0.00 & 8.38 & 4.88 & 4.28 & 3.96 & 4.11 \\
\hline Çeşit $L S D_{0.05}$ & $16.6^{*}$ & Ö.D. & $19.2^{*}$ & $3.19^{*}$ & $10.2^{*}$ & $3.44^{*}$ & $2.35^{*}$ & $2.66^{*}$ & $1.14^{*}$ & Ö.D. & $0.54^{*}$ & $0.22^{*}$ & $1.41^{*}$ & 2.88 & $1.03^{*}$ & $0.02^{*}$ & $0.02^{*}$ & $0.01^{*}$ \\
\hline Çeşit*Yıl LSD 0.05 & & & Ö. D. & & & $4.87^{*}$ & & & $1.62^{*}$ & & & $0.31^{*}$ & & & Ö. D. & & & $0.01^{*}$ \\
\hline
\end{tabular}

*:\% 5 önem seviyesinde önemli, Ö.D. Önemli değil 